\title{
Investigations of tungsten mine waste geopolymeric binder: Strength and microstructure
}

\author{
Fernando Pacheco-Torgal $^{\text {a,* }}$, J.P. Castro-Gomes ${ }^{\text {b,1 }}$, Said Jalali ${ }^{c, 2}$ \\ ${ }^{a}$ Castelo Branco Polytechnic Institute, Department of Civil Engineering, 6000 Castelo Branco, Portugal \\ ${ }^{\mathrm{b}}$ University of Beira Interior, Department of Civil Engineering, 6200 Covilhã, Portugal \\ ${ }^{\mathrm{c}}$ University of Minho, Department of Civil Engineering, 4800 Guimarães, Portugal
}

Received 10 February 2007; received in revised form 15 August 2007; accepted 15 August 2007

Available online 4 October 2007

\begin{abstract}
This paper reports some results of a research project related to the development of a new binder using mineral waste mud from the Portuguese mine. Some aspects related to the effect of aggregates in the microstructure and mechanical behaviour of tungsten mine waste geopolymeric binder are reported in the present study. Test results showed that the aggregate type influences strength development. (C) 2007 Elsevier Ltd. All rights reserved.
\end{abstract}

Keywords: Binder; Mine waste mud; Interfacial transition zone

\section{Introduction}

In 1978, Davidovits created the term "geopolymer", to characterize new materials with the ability to transform, polycondense and adopt a shape rapidly at low temperatures like "polymers" [1]. Davidovits reported several advantages of geopolymeric cementitious systems over Portland cement mainly environmental, due to the fact that geopolymeric based concrete has a much longer service life than Portland cement based ones, to the metals waste encapsulation capacity and to lower $\mathrm{CO}_{2}$ emissions, 0.18 tonnes of $\mathrm{CO}_{2}$ per tonne of cement [2]. Geopolymerisation involves a chemical reaction between various alumino-silicate oxides with silicates under highly alkaline conditions, yielding polymeric $\mathrm{Si}-\mathrm{O}-\mathrm{Al}-\mathrm{O}$ bonds indicating that only $\mathrm{Si}-\mathrm{Al}$ materials might become sources of geopolymerisation. They require a precursor that contains significant quantities of silicon and aluminium held in an amorphous

\footnotetext{
${ }^{*}$ Corresponding author. Tel.: +351 272 339300; fax: +351 272339399.

E-mail addresses: fernandotorgal@est.ipcb.pt (F. Pacheco-Torgal), castro.gomes@ubi.pt (J.P. Castro-Gomes), said@civil.uminho.pt (S. Jalali).

${ }^{1}$ Tel.: +351 275 329990; fax: +351 275329969 .

${ }^{2}$ Tel.: +351 253 510200; fax: +351253510213.
}

phase such as ashes from power stations or mining and quarrying wastes.

Tungsten mine waste mud geopolymeric binder is a new cementitious material obtained from dehydroxylated mine waste powder mixed with minor quantities of calcium hydroxide and activated with $\mathrm{NaOH}$ and waterglass solutions [3]. It has a very high early age strength, low water absorption and very good adhesion to OPC concrete [4-6].

However much remains to be found about this new binder, for instance if different aggregates influence the strength behaviour and how that happens. In truth it's still not clear how aggregates behave in highly alkaline binders. Therefore, in this study the effect of the aggregate/binder ratio, the aggregate dimension and aggregate type, schist, granite and limestone in the microstructure and mechanical behaviour of tungsten mine waste geopolymeric pastes and mortars is investigated.

\section{Experimental program}

\subsection{Materials}

Mineralogical composition and thermal conditions were described elsewhere [3]. The XRD patterns indicated that 
mine waste mud consists mainly of muscovite and quartz which were identified by their characteristic patterns as follows: muscovite (card 46-1409) and quartz (card 46-1045). The chemical composition and specific surface of the mine waste mud are shown in Table 1. Table 2 shows gradation and physical characteristics of aggregates. Limestone and granitic coarse aggregates have the same Faury maximum dimension (9.52) and similar fineness modulus respectively 5.5 and 5.2. Schist sand has a lower maximum dimension (2.78) and a fineness modulus of 2.38 .

\subsection{Mix proportion, strength testing and microanalysis of the binders}

In this investigation the mortar was a mixture of aggregates, waste mud, calcium hydroxide, alkaline silicate solution and water. The mass ratio of tungsten mine waste mud: activator was 1:1. Calcium hydroxide was used with a percentage substitution of $10 \%$, because it was found that percentage leads to the highest compressive strengths. An activator with sodium hydroxide $(24 \mathrm{M})$ and sodium silicate solution $\left(\mathrm{Na}_{2} \mathrm{O}=8.6 \%, \mathrm{SiO}_{2}=27.8 \%, \mathrm{Al}_{2} \mathrm{O}_{3}=0.4 \%\right.$ and water $=63.2 \%$ ) was used with a mass ratio of 1:2.5.

Table 1

Chemical composition and specific surface

\begin{tabular}{lc}
\hline Constituents (\%) & Mine waste mud \\
\hline $\mathrm{SiO}_{2}$ & 53.48 \\
$\mathrm{Al}_{2} \mathrm{O}_{3}$ & 16.66 \\
$\mathrm{Fe}_{2} \mathrm{O}_{3}$ & 12.33 \\
$\mathrm{~K}_{2} \mathrm{O}$ & 7.65 \\
$\mathrm{Na}_{2} \mathrm{O}$ & 0.62 \\
$\mathrm{MgO}$ & 1.27 \\
$\mathrm{SO}_{4}$ & 3.10 \\
$\mathrm{TiO}_{2}$ & 1.39 \\
$\mathrm{As}$ & 1.28 \\
$\mathrm{Other}$ minor oxides & 2.22 \\
Blaine fineness $\left(\mathrm{m}^{2} / \mathrm{kg}\right)$ & 357 \\
\hline
\end{tabular}

Table 2

Gradation and physical characteristics of aggregates

\begin{tabular}{lccc}
\hline & \multicolumn{3}{l}{ Cumulative percentage retained } \\
\cline { 2 - 4 } & Schist (SC) & Limestone (LS) & Granite (GR) \\
\cline { 2 - 4 } & Sand & Coarse aggregate & \\
\hline $9.5 \mathrm{~mm}$ & 0 & 0 & 0 \\
$4.76 \mathrm{~mm}$ & 0 & 62.9 & 35.4 \\
$2.38 \mathrm{~mm}$ & 0.9 & 89.1 & 91.5 \\
$1.19 \mathrm{~mm}$ & 28.3 & 99.3 & 97.2 \\
$590 \mu \mathrm{m}$ & 62.2 & 99.4 & 98.5 \\
$297 \mu \mathrm{m}$ & 88.8 & 99.4 & 99.2 \\
$149 \mu \mathrm{m}$ & 98.7 & 99.7 & 99.4 \\
$74 \mu \mathrm{m}$ & 99.8 & 99.8 & 99.6 \\
Dust content $(<74 \mu \mathrm{m})$ & 0.2 & 0.2 & 0.4 \\
Fineness modulus & 2.78 & 5.5 & 5.2 \\
Max. dimension $(\mathrm{mm})$ & 2.38 & 9.52 & 9.52 \\
Water absorption $(\%)$ & 0.9 & 0.8 & 0.4 \\
Density $\left(\mathrm{kg} / \mathrm{m}^{3}\right)$ & 2703 & 2659 & 2689 \\
\hline
\end{tabular}

Table 3

Samples composition (in mass)

\begin{tabular}{|c|c|c|c|c|c|c|}
\hline \multirow[t]{2}{*}{ Samples } & \multicolumn{2}{|l|}{ Binder } & \multicolumn{2}{|c|}{ Activator } & \multirow{2}{*}{$\begin{array}{l}\text { Extra } \\
\text { water } \\
(\%)\end{array}$} & \multirow[t]{2}{*}{ Aggregates } \\
\hline & $\begin{array}{l}\mathrm{Ca}(\mathrm{OH})_{2} \\
(\%)\end{array}$ & $\begin{array}{l}\text { Mine } \\
\text { waste } \\
(\%)\end{array}$ & $\begin{array}{l}\mathrm{NaOH} \\
(\%)\end{array}$ & $\begin{array}{l}\text { Waterglass } \\
(\%)\end{array}$ & & \\
\hline PCP & 10 & 90 & 28.57 & 71.43 & 0 & 0 \\
\hline $\mathrm{Ag} / \mathrm{B}=0.5$ & & & & & 3.6 & 0.5 \\
\hline $\mathrm{Ag} / \mathrm{B}=0.75$ & & & & & & 0.75 \\
\hline $\mathrm{Ag} / \mathrm{B}=1.0$ & & & & & & 1.0 \\
\hline $\mathrm{Ag} / \mathrm{B}=1.5$ & & & & & 7 & 1.5 \\
\hline $\mathrm{Ag} / \mathrm{B}=1.7$ & & & & & 10 & 1.7 \\
\hline
\end{tabular}

Previous investigations showed that this ratio leads to the highest compressive strength results in alkali-activated mine waste mud mortars [5]. Distilled water was used to dissolve the sodium hydroxide flakes to avoid the effect of unknown contaminants in the mixing water. The alkaline activator was prepared prior to use. The sand, mine waste mud and calcium hydroxide were dry mixed before being added to the activator. The mass ratio of water/dry solid binder content was $3.6 \%$ in most of the samples, except for samples with an aggregate/binder mass ratio of 1.5 or 1.7 in those cases, the extra water percentages were respectively $7 \%$ and $10 \%$. The samples composition is shown in Table 3.

Compressive strength data was obtained using $50 \times 50 \times 50 \mathrm{~mm}^{3}$ cubic specimens. The fresh mortar was cast and allowed to set at room temperature for $24 \mathrm{~h}$ before being removed from the moulds and kept at room temperature until tested in compression. Compressive strength for each mixture was obtained from an average of three cubic specimens determined at the age of 1, 3, 7, 14 and 28 days of curing.

For examination by scanning electron microscopy (SEM) mortar samples were embedded into a low viscosity epoxy resin, cut and polished. After the lapping stage an additional epoxy impregnation was performed, and the samples were relapped in order to ensure full resin impregnation and a good quality polish. The samples were then carbon-coated. A Hitachi S2700 scanning electron microscope was used equipped with a solid backscattered detector and a Rontec energy dispersive (EDS) X-ray microanalysis system.

\section{Results and discussion}

\subsection{Compressive strength}

Compressive strength of tungsten mine waste geopolymeric binder is shown in Figs. 1 and 2. Plain geopolymeric mine waste paste was named PCP. Geopolymeric binder using schist (SC) fine aggregates with an aggregate/binder ratio of 0.5 were named SC - AG/B 0.5. Similarly when limestone (LS) or granite (GR) aggregates were used, they were named respectively LS $-\mathrm{AG} / \mathrm{B} 0.5$ and $\mathrm{GR}-\mathrm{AG} / \mathrm{B}$ 0.5 . 
This new binder showed very high strength at early ages, even higher than geopolymeric mixtures made with more reactive aluminosilicate raw materials like metakaolin [7]. It seems that strength level is due to calcium hydroxide and iron oxide which provides extra potential nucleation sites [5]. Compressive strength of tungsten mine waste geopolymeric binder made with schist sand are very similar when aggregate/binder ratio varies from 0.5 to 1.5 (Fig. 1a). That assumption is not valid to an aggregate/binder ratio of 1.7 mostly because to keep a similar workability more water has been added to the mixture. Therefore, when $\mathrm{H}_{2} \mathrm{O} / \mathrm{Na}_{2} \mathrm{O}$ molar ratio is increased to 11.4 it leads to a strength decrease. Previous studies about geopolymeric mine waste mud mortars showed that $\mathrm{H}_{2} \mathrm{O} / \mathrm{Na}_{2} \mathrm{O}$ molar

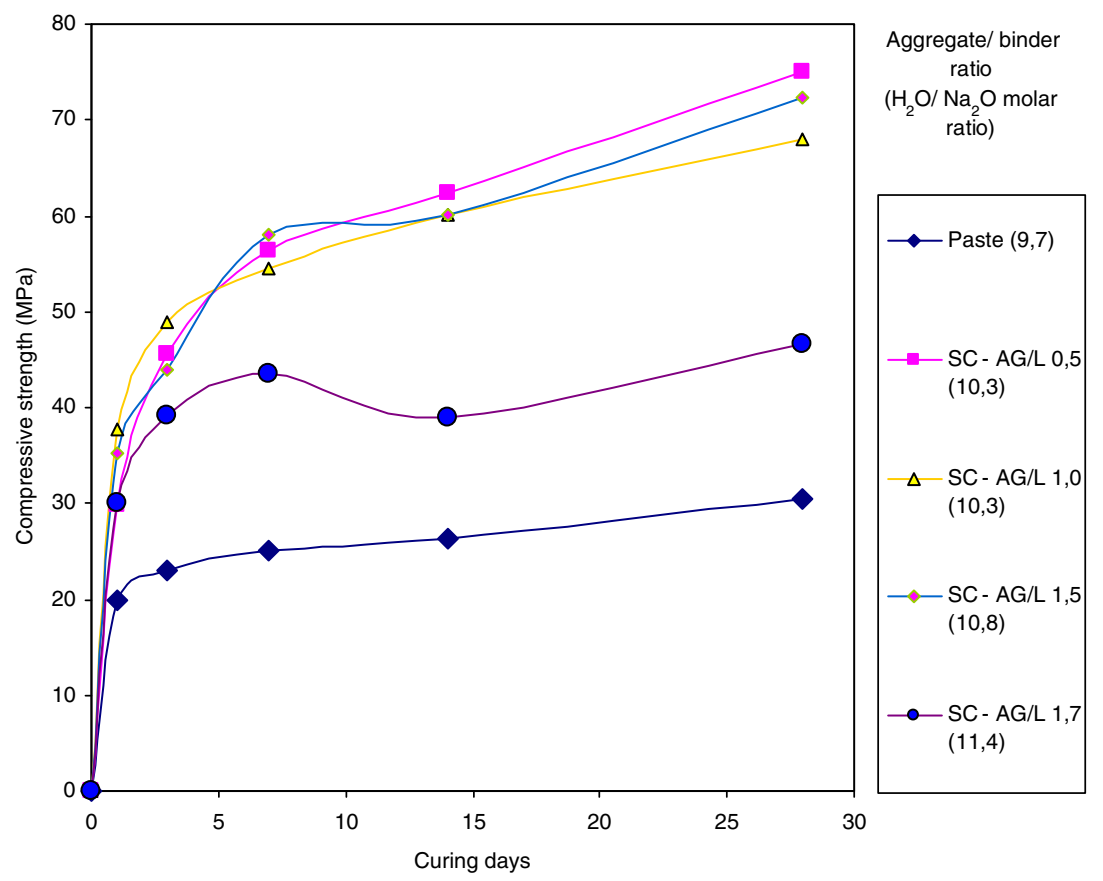

Fig. 1a. Compressive strength according to aggregate/binder mass ratio and $\mathrm{H}_{2} \mathrm{O} / \mathrm{Na}_{2} \mathrm{O}$ molar ratio in tungsten mine waste geopolymeric binder made with schist fine aggregates.

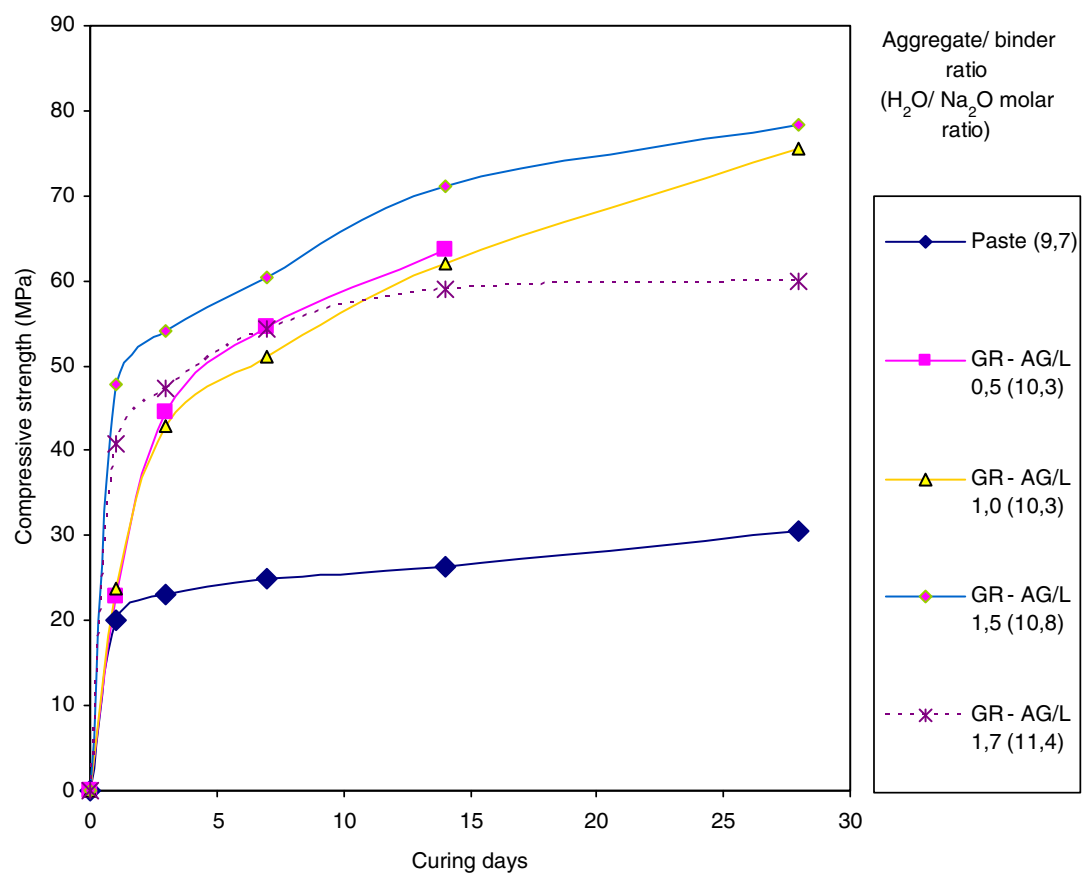

Fig. 1b. Compressive strength according to aggregate/binder mass ratio and $\mathrm{H}_{2} \mathrm{O} / \mathrm{Na}_{2} \mathrm{O}$ molar ratio in tungsten mine waste geopolymeric binder made with limestone coarse aggregates. 


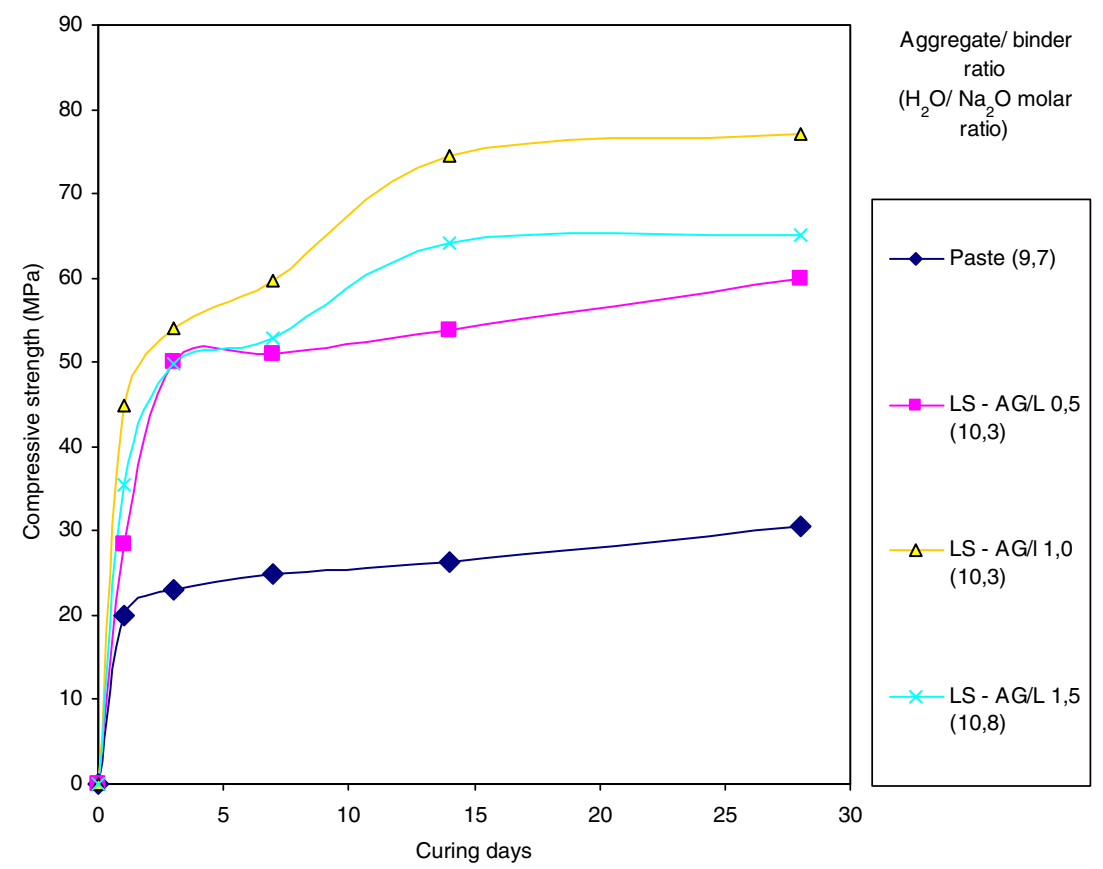

Fig. 1c. Compressive strength according to aggregate/binder mass ratio and $\mathrm{H}_{2} \mathrm{O} / \mathrm{Na}_{2} \mathrm{O}$ molar ratio in tungsten mine waste geopolymeric binder made with granitic coarse aggregates.

ratio is a very significant parameter being closely related to compressive strength. Compressive strength increases due to less water and hence less porosity in the gel. And also when $\mathrm{H}_{2} \mathrm{O} / \mathrm{Na}_{2} \mathrm{O}$ molar ratio decrease due to higher $\mathrm{NaOH}$ concentration. Increasing $\mathrm{NaOH}$ concentration provides better dissolution of silicate and aluminate species leading to increased inter-molecular bond strength. The adverse effect reported by Lee and Van Deventer [8] related to reduction in strength due to excess of alkali, has not been confirmed. This subject requires further investigations. However it must be a subject related to setting rate, because faster rates give less time for dissolution leading to more unreacted particles and strength reduction, so it may be expected that those authors used more reactive material (fly ash and kaolin) than mine waste mud used in the present work.

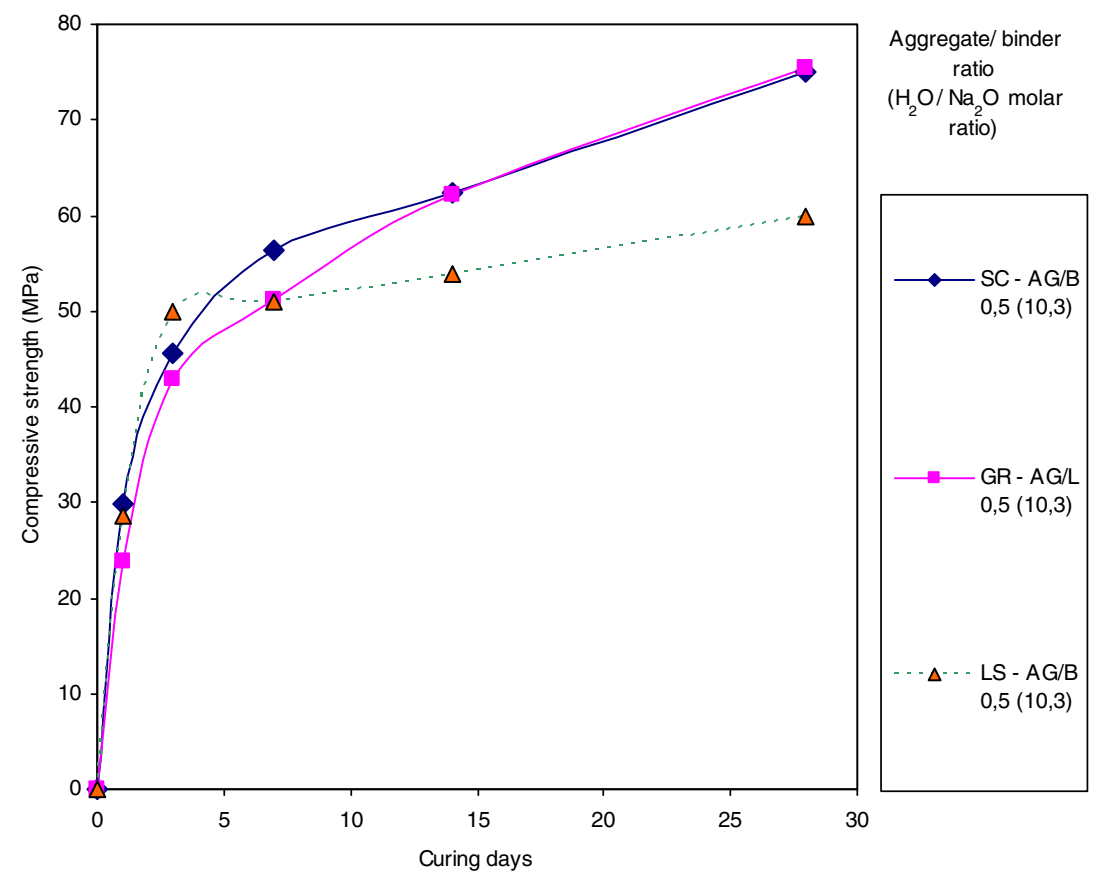

Fig. 2a. Compressive strength in tungsten mine waste geopolymeric mortars made with an aggregate/binder mass ratio $=0.5$. 


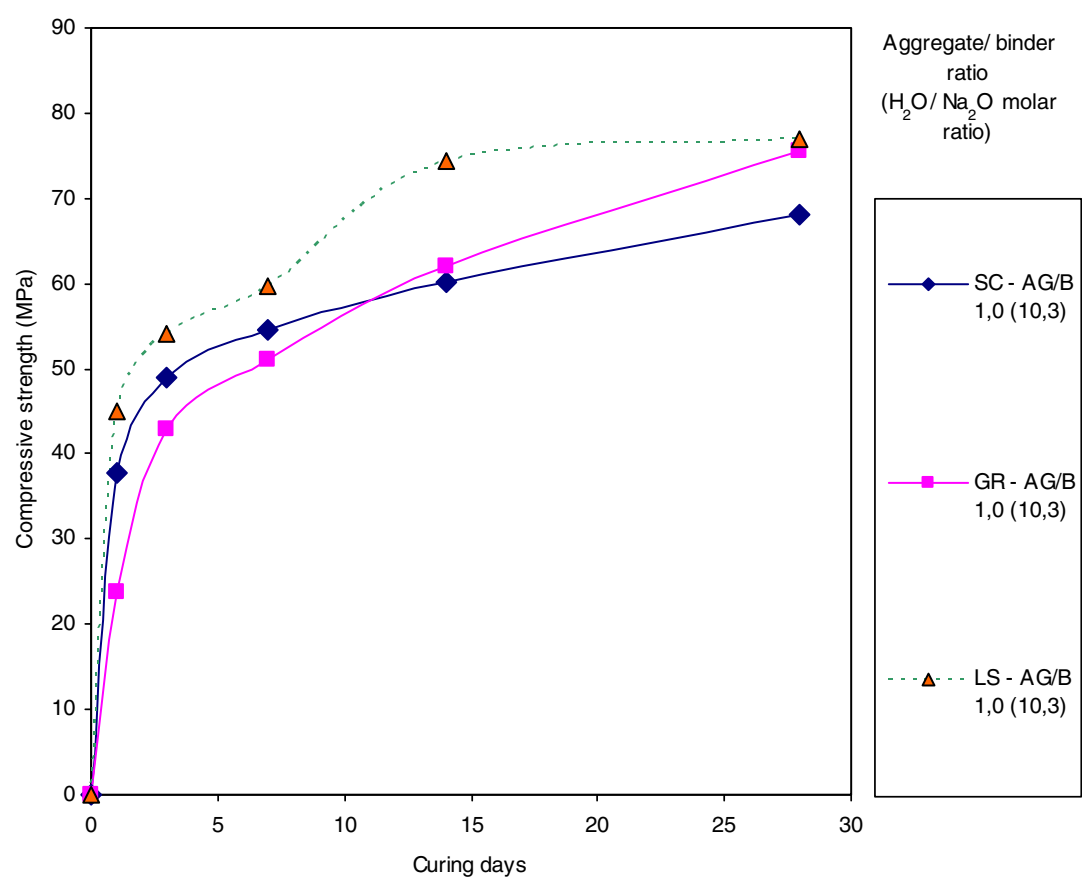

Fig. 2b. Compressive strength in tungsten mine waste geopolymeric mortars made with an aggregate/binder mass ratio $=1.0$.

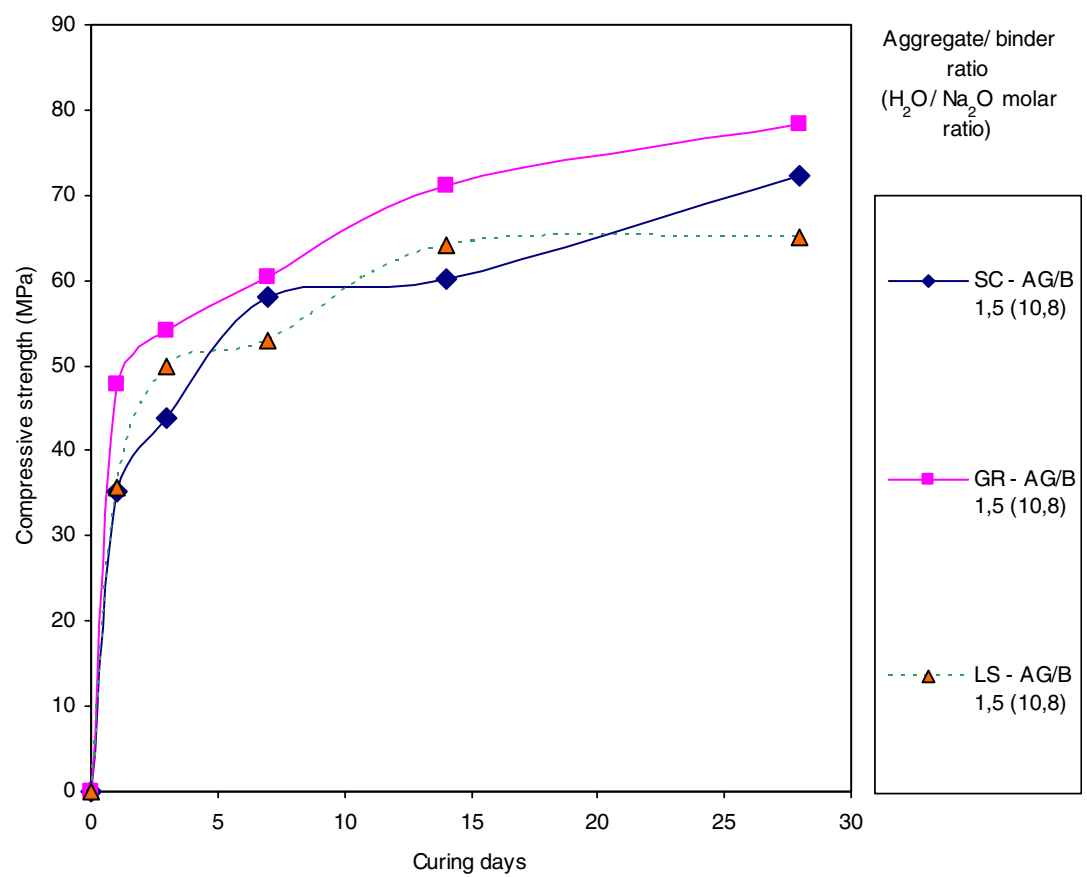

Fig. 2c. Compressive strength in tungsten mine waste geopolymeric mortars made with an aggregate/binder mass ratio $=1.5$.

Similar behaviour happens when mixtures with coarse granitic aggregates are used, the only difference is that compressive strength of the mixtures with an aggregate/binder ratio of 1.7 shows a decrease in strength only after 14 days (Fig. 1c). Compressive strength of geopolymeric paste is significantly lower than compressive strength of geopolymeric mortars independent of aggregate type. In conventional concrete, the aggregates form a rigid skeleton of granular elements which are responsible for compressive strength. In the case of mortars with low content of aggregates, i.e. aggregate/binder mass ratio below 2.0 aggregates do not form a rigid skeleton but a set of inclusions trapped in a continuous paste matrix. One suggests that strength behaviour can only be explained by the chemically active role played by the aggregates, which may be due to the dissolution of quartz in the presence of alkalis enhancing 
bond between paste aggregates as reported by Shi and Xie [9] and even despite the low solubility of aluminosilicate minerals in alkaline medium. Furthermore the similar strength results obtained when using aggregates with different size and water absorption (Schist and granite) prevents the explanation relying on the localized water near them, as it happens in OPC systems. For an aggregate/binder ratio of 0.5 the geopolymeric mortar mixtures with limestone aggregates achieve a maximum strength at early ages and that strength level keeps stable with curing age (Fig. 2a). For the same aggregate/binder ratio silicon based aggregates (granite and schist) showed increased strength with curing time. That behaviour is somehow different from OPC systems where mixtures with the same water/binder present similar mechanical behaviour independently of the different aggregates used.

\subsection{Scanning electron microscopy analysis}

Figs. 3 and 4 shows SEM micrographs of tungsten mine waste geopolymeric binder. The analyses carried out by EDS on the different samples are displayed in Tables 4 and 5. In Fig. 3 it is possible to see a scanning electron micrograph of a mortar sample, showing the existence of two different gel phases according to EDS analyses (Fig. 3a). This finding confirms the formation of geopolymeric gel (areas $\mathrm{X}$ and $\mathrm{Y}$ ), as the main reaction product of Al-Si materials in presence of calcium hydroxide when submitted to high alkaline solutions, as stated by Alonso and Palomo [10]. High hydroxyl concentration prevents the calcium hydroxide dissolution, so only small amounts of calcium will participate in the formation of $\mathrm{CSH}$. The area identified as $\mathrm{Z}$ (Fig. 3b), has a low $C / S$ ratio which

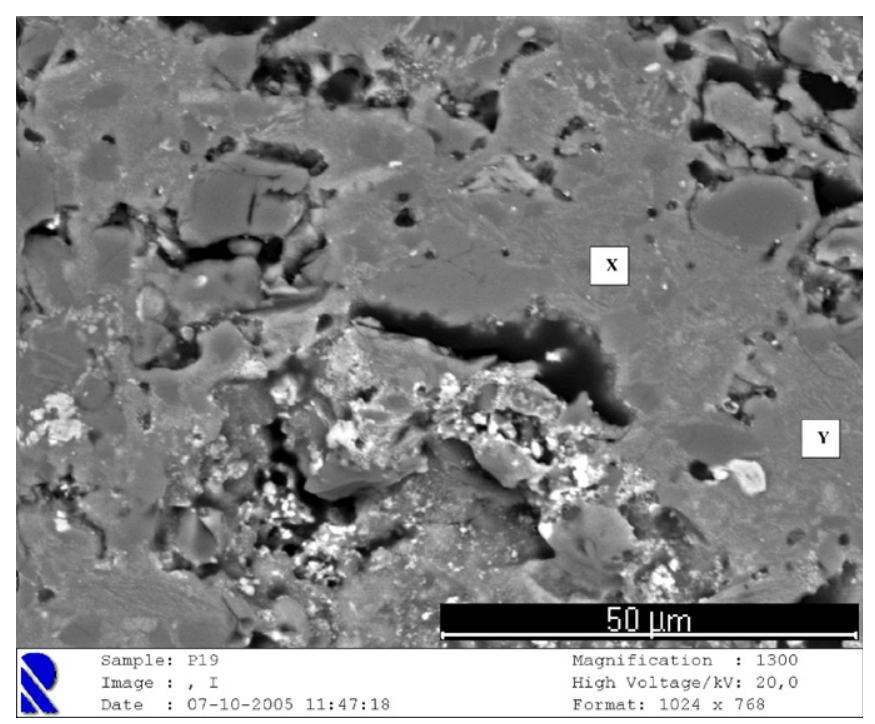

Fig. 3a. SEM micrographs of tungsten mine waste geopolymeric mortar. The areas marked as $\mathrm{X}$ and $\mathrm{Y}$ are identified as some type of aluminosilicate with the following composition: $\mathrm{X}\left[\left(\mathrm{CaO} / \mathrm{SiO}_{2}=0\right) ;\left(\mathrm{Al}_{2} \mathrm{O}_{3} /\right.\right.$ $\left.\mathrm{Na}_{2} \mathrm{O}_{\mathrm{eq}}=2.5\right)$ and $\left(\mathrm{SiO}_{2} / \mathrm{Al}_{2} \mathrm{O}_{3}=4\right) ; \mathrm{Y} \quad\left[\left(\mathrm{CaO} / \mathrm{SiO}_{2}=0\right) ; \quad\left(\mathrm{Al}_{2} \mathrm{O}_{3} /\right.\right.$ $\left.\mathrm{Na}_{2} \mathrm{O}_{\text {eq }}=3.1\right)$ and $\left(\mathrm{SiO}_{2} / \mathrm{Al}_{2} \mathrm{O}_{3}=3.1\right)$.

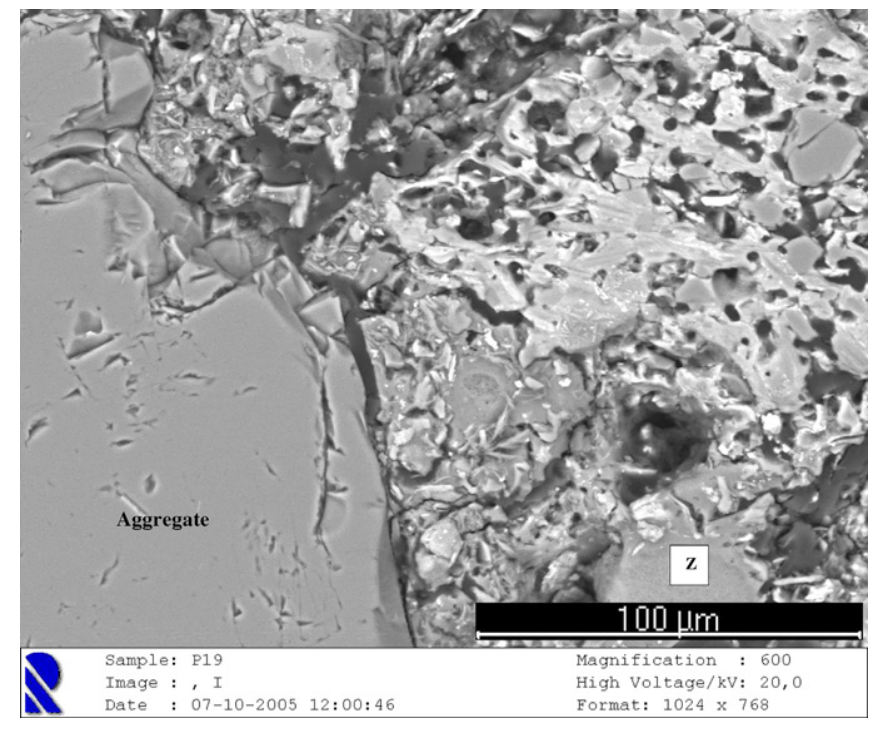

Fig. 3b. SEM micrographs of tungsten mine waste geopolymeric mortar. The area marked as $\mathrm{Z}$ is identified as some form of calcium silicate with some sodium and with traces of aluminium in its composition $(\mathrm{CaO} /$ $\left.\mathrm{SiO}_{2}=0.8\right) ;\left(\mathrm{Al}_{2} \mathrm{O}_{3} / \mathrm{Na}_{2} \mathrm{O}_{\mathrm{eq}}=0.3\right)$ and $\left(\mathrm{SiO}_{2} / \mathrm{Al}_{2} \mathrm{O}_{3}=20.2\right)$.

means it as some sodium replacing $\mathrm{Ca}^{2+}$ in $\mathrm{CSH}$; some authors have already demonstrated that sodium incorporation in $\mathrm{CSH}$ phase increased as $C / S$ ratio decreases, and therefore, they name it as NSH [11].

Aluminosilicates with similar $\mathrm{SiO}_{2} / \mathrm{Al}_{2} \mathrm{O}_{3}$ and $\mathrm{Al}_{2} \mathrm{O}_{3} /$ $\mathrm{Na}_{2} \mathrm{O}$ molar ratios were found by Yip et al. $[12,13]$. Those authors also found the existence of an optimum of $20 \%$ (about $9 \%$ of calcium oxide) slag content in alkali-activation of metakaolin-slag mixtures, leading to increased compressive strength, which according to them can be explained by the fact that formed CSH within the geopoly-

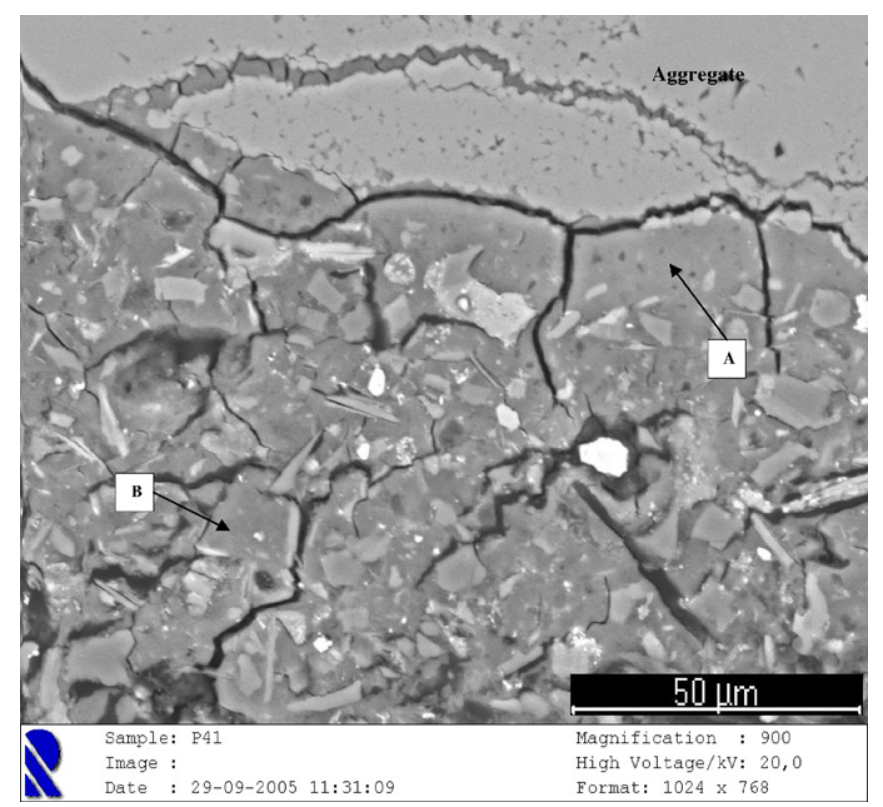

Fig. 4a. SEM micrographs of interfacial transition zone in tungsten mine waste geopolymeric mortars made with limestone coarse aggregates. 


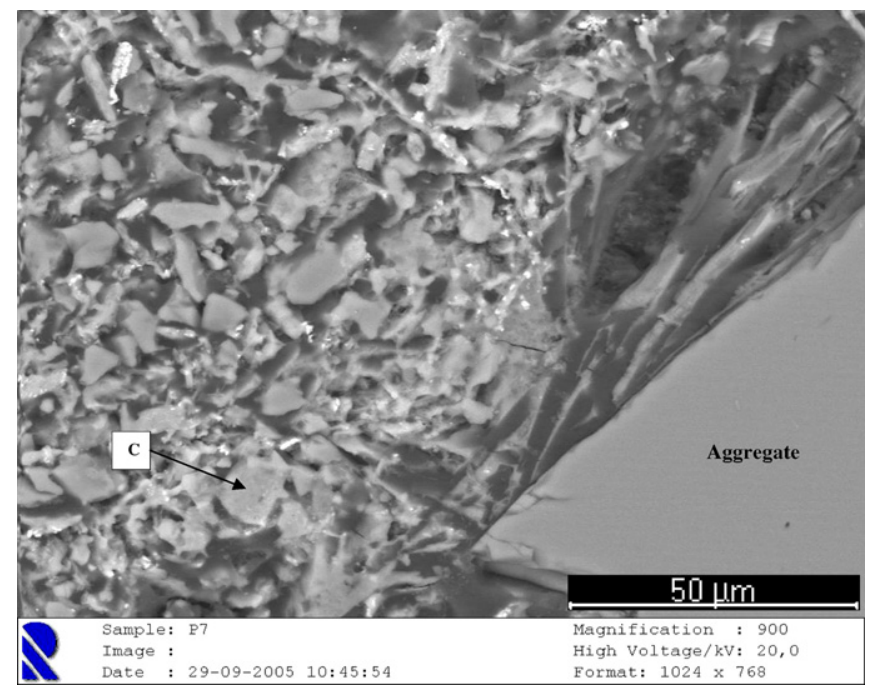

Fig. 4b. SEM micrographs of interfacial transition zone in tungsten mine waste geopolymeric mortars made with schist fine aggregates.

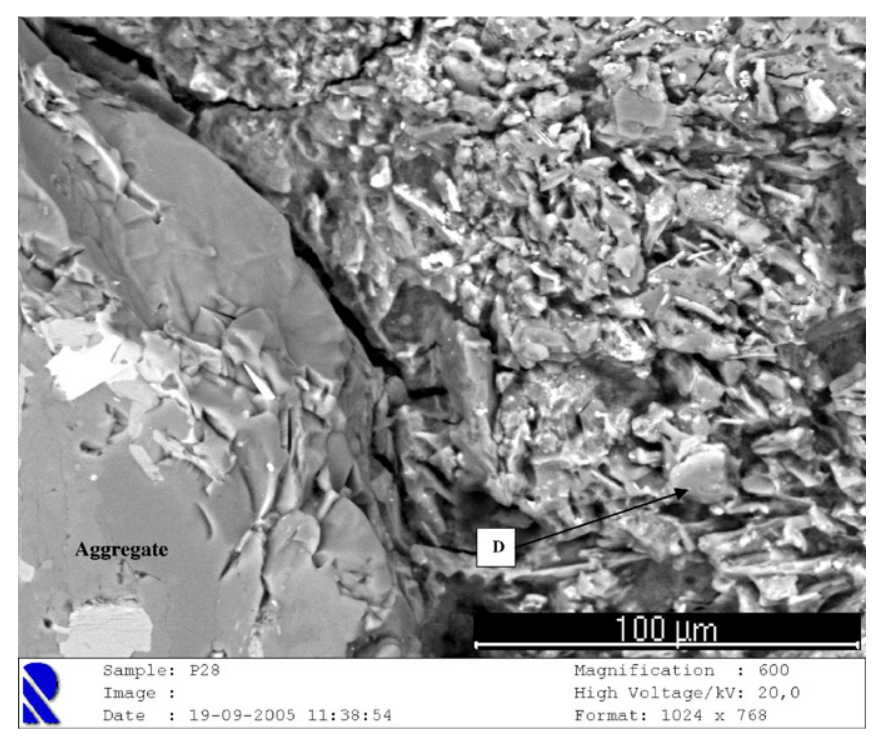

Fig. 4c. SEM micrographs of interfacial transition zone in tungsten mine waste geopolymeric mortars made with granitic coarse aggregates.

Table 4

EDS analysis

\begin{tabular}{|c|c|c|c|c|}
\hline \multirow[t]{3}{*}{ Oxides $(\%)$} & \multicolumn{4}{|c|}{ Mortar sample according to aggregate type } \\
\hline & \multicolumn{2}{|c|}{ Limestone (LS) } & \multirow{2}{*}{$\begin{array}{l}\text { Schist (SC) } \\
\mathrm{C}\end{array}$} & \multirow{2}{*}{$\begin{array}{l}\text { Granite (GR } \\
\mathrm{D}\end{array}$} \\
\hline & A & B & & \\
\hline $\mathrm{SiO}_{2}$ & 49.2 & 51.1 & 53.1 & 39.4 \\
\hline $\mathrm{Al}_{2} \mathrm{O}_{3}$ & - & 7.5 & 28.8 & 13.9 \\
\hline $\mathrm{Fe}_{2} \mathrm{O}_{3}$ & - & 4.8 & 3.5 & 27.4 \\
\hline $\mathrm{K}_{2} \mathrm{O}$ & 1.8 & 2.6 & 9.2 & 8.9 \\
\hline $\mathrm{CaO}$ & 36.1 & 24.1 & 0.8 & 2.6 \\
\hline $\mathrm{MgO}$ & 1.9 & - & 2.9 & 4.4 \\
\hline $\mathrm{Na}_{2} \mathrm{O}$ & 8.8 & 9.9 & 1.7 & 3.4 \\
\hline $\mathrm{TiO}_{2}$ & - & - & - & - \\
\hline $\mathrm{SO}_{3}$ & 2.2 & - & - & - \\
\hline
\end{tabular}

Table 5

Atomic ratio analysis

\begin{tabular}{|c|c|c|c|c|c|}
\hline \multirow[t]{3}{*}{ Atomic ratio } & \multirow[t]{3}{*}{$\begin{array}{l}\text { Tungsten mine } \\
\text { waste mud }\end{array}$} & \multicolumn{4}{|c|}{$\begin{array}{l}\text { Mortar sample according to aggregate } \\
\text { type }\end{array}$} \\
\hline & & \multicolumn{2}{|c|}{$\begin{array}{l}\text { Limestone } \\
\text { (LS) }\end{array}$} & \multirow{2}{*}{$\begin{array}{l}\text { Schist (SC) } \\
\mathrm{C}\end{array}$} & \multirow{2}{*}{$\begin{array}{l}\text { Granite (GR } \\
\mathrm{D} \\
\end{array}$} \\
\hline & & A & $\mathrm{B}$ & & \\
\hline $\mathrm{SiO}_{2} / \mathrm{Al}_{2} \mathrm{O}_{3}$ & 5.5 & - & 11.6 & 3.3 & 4.8 \\
\hline $\mathrm{Al}_{2} \mathrm{O}_{3} / \mathrm{Na}_{2} \mathrm{O}_{\mathrm{eq}}$ & 1.8 & - & 0.4 & 2.2 & 0.9 \\
\hline $\mathrm{CaO} / \mathrm{SiO}_{2}$ & - & 0.8 & 0.5 & 0.02 & 0.07 \\
\hline $\mathrm{Na}_{2} \mathrm{O}_{\mathrm{eq}} / \mathrm{CaO}$ & - & 0.25 & 0.4 & 8.8 & 3.1 \\
\hline $\mathrm{Al}_{2} \mathrm{O}_{3} / \mathrm{CaO}$ & - & - & 0.2 & 19.6 & 3.0 \\
\hline $\mathrm{MgO} / \mathrm{Al}_{2} \mathrm{O}_{3}$ & 0.2 & - & - & 0.25 & 0.8 \\
\hline $\mathrm{Fe}_{2} \mathrm{O}_{3} / \mathrm{Al}_{2} \mathrm{O}_{3}$ & 0.5 & - & 0.4 & 0.08 & 1.3 \\
\hline
\end{tabular}

meric binder acts as microaggregates resulting in a dense and homogeneous binder. Furthermore increased calcium content leads to minor reactant aluminosilicate species dissolved. Be there as it may, is still not clear why calcium hydroxide plays such a significant role in the strength of geopolymeric binder. Fig. 4 shows SEM micrographs of the interfacial transition zone (ITZ) in mixtures of geopolymeric mortars made with different aggregates and Tables 4 and 5 shows the results of SEM/EDS analysis.

In contrast with the porous typical interfacial transition zone of Portland cement mixtures, geopolymeric mortars present a very dense and uniform ITZ. The SEM images taken on the limestone based mixtures show that paste chemically bond to the aggregate. That explains why in limestone based mixtures, to the same $\mathrm{H}_{2} \mathrm{O} / \mathrm{Na}_{2} \mathrm{O}$ molar ratio an increase in aggregate content from an aggregate/binder ratio of 0.5 to an aggregate/binder ratio of 1.0 leads to an increase in compressive strength. However clear cracks can be seen indicating shrinkage due to excess of calcium as suggested previously helping to explain some random strength behaviour. The chemical composition of area A shows (Fig. 4a) a sílica gel with some sodium and some calcium, being some of the calcium due to the aggregate. As for area B (Fig. 4a), it seems to be made from sílica gel with some sodium, aluminium and less calcium, meaning calcium content decreases with increased distance from aggregates. Area D (Fig. 4c) presents a sodium content above the one presented by area C (Fig. 4b), that may be explained by the fact that aggregate distance is also higher, meaning that sodium incorporation could be influenced by species dissolution from aggregates.

The $\mathrm{SiO}_{2} / \mathrm{Al}_{2} \mathrm{O}_{3}$ in areas marked as $\mathrm{C}$ and $\mathrm{D}$ is lower than in the waste mud, due to increased aluminium content. That behaviour is related to the silica and alumina reactivity of the original mineral as stated before; authors think that some aluminium will be dissolved from the aggregates to participate in the geopolymerization process, although further research is still needed in order to confirm that assumption. That hypothesis is consistent with the behaviour presented by binders with aluminosilicate aggregates, which present higher compressive strength. 


\section{Conclusions}

The following conclusions can be drawn from this study:

Aggregates seem to increase strength behaviour of tungsten mine waste geopolymeric binder. It's suggested that may be due to the dissolution of quartz and alumina in the presence of alkalis enhancing bonding between paste and aggregates. In alkali-activated based binders schist and granitic aggregates are chemically reactive increasing strength with curing time. In contrast with the porous typical interfacial transition zone of Portland cement mixtures, a dense and uniform interfacial transition zone was detected in tungsten mine waste geopolymeric based binders.

\section{Acknowledgements}

The writers would like to thank the Optical Centre of University of Beira Interior for helping in SEM/EDS investigations.

\section{References}

[1] Davidovits J. Geopolymers: inorganic polymeric new materials. J Therm Anal 1991;37:1633-56.

[2] Davidovits J. Environmentally driven geopolymer cement applications. In: Proceedings of 2002 geopolymer conference, Melbourne, Australia.
[3] Pacheco-Torgal F, Castro-Gomes JP, Jalali S. Geopolymeric binder using tungsten mine waste: preliminary investigation. In: Proceedings of geopolymer 2005 world congress, Saint Quentin, France. 2005. p. 93-8.

[4] Pacheco-Torgal F, Castro-Gomes JP, Jalali S. Adhesion characterization of tungsten mine waste geopolymeric binder. Influence of OPC concrete substrate surface treatment. Construct Build Mater 2008;22(3):154-61.

[5] Pacheco-Torgal F, Castro-Gomes JP, Jalali S. Investigations on mix design of tungsten mine waste geopolymeric binder. Construct Build Mater 2008;22(9):1939-49.

[6] Pacheco-Torgal F, Castro-Gomes JP, Jalali S. Properties of tungsten mine waste geopolymeric binder. Construct Build Mater 2008;22(6):1201-11.

[7] Pinto AT. Metakaolin alkali-activated based binders. PhD Thesis, University of Minho, Portugal. 2004 [in Portuguese].

[8] Lee WKW, Van Deventer JSJ. The effects of inorganic salt contamination on the strength and durability of geopolymers. Colloids Surf 2002;211:115-26.

[9] Shi Caijun, Xie P. Interface between cement paste and quartz sand in alkali-activated slag mortars. Cement Concrete Res 1998;28:887-96.

[10] Alonso S, Palomo A. Alkaline activation of metakaolin and calcium hydroxide mixtures: influence of temperature, activator concentration and solids ratio. Mater Lett 2001;47:55-62.

[11] Macphee DE. Solubility and aging of calcium silicate hydrates in alkaline solutions at $25^{\circ} \mathrm{C}$. J Am Ceram Soc 1989;72:646-54.

[12] Yip CK, Deventer SJS. Microanalysis of calcium silicate hydrate gel formed within a geopolymeric binder. J Mater Sci 2003;38:3851-60.

[13] Yip CK, Lukey GC, Deventer SJS. The coexistence of geopolymeric gel and calcium silicate hydrate gel at the early stage of alkaline activation. Cement Concrete Res 2005. 